\title{
BUILDINGS SPEAK TO US
}

\section{A B S T R A C T}

Starting with a critical view of the general architectural and urban structures of today my paper will present buildings comparable to the body, thus their expression and the meanings they invoke will be presented as a language of form that affect the behavior and psychology of urban residents. Referring to the architectural criticisms of George Bataille, it is argued that the physicality of buildings are valuable insofar as they transcend materiality and lead to symbols and spirituality. Buildings are viewed as presenting different characteristics and attitudes depending on their form. Architecture is also viewed as the product of labour and thus a communal creation that has its roots in the origins of human culture. Each different institution has evolved historically from different senses becoming cultural articulations and resulting in architectures that connect people in enjoyment of shared interests. It is further argued that urban and spatial forms that are confusing as to their boundaries and appertainance can cause confusion and negative reactions. Thus it is important that urban forms' language is positive and clear.

\author{
Jale N. Erzen \\ Middle East Technical University \\ jaleerzen@gmail.com
}

KEY WORDS

ARCHITECTURE

BODY

LANGUAGE

FORM

CULTURE 
In this contribution I would like to approach the state of architecture and our relation to it within the city. As I dwell on its multiple assets that are constructive of the city atmosphere, I am constantly reminded of how all along history each minute form, from a cornice to a balustrade, from the curvature of stairs to the frames of windows, the height of ceilings, the position of doors, and the size of rooms and spaces, etc., were studied and calculated endless times before acquiring their final form. What we mostly see today is the sprouting of competitive erections, whose most telling feature is a flat silhouette and imposing physicality.

As our essential living means architecture can be seen from many viewpoints: aesthetic, practical, political, economic, etc. My aesthetic evaluation of the architectural body in the urban context will deal with its meaning and how it speaks to us: its language. This will be an implicit political criticism, which was basically George Bataille's approach. ${ }^{1}$

Architecture conditions our most intimate and, at the same time, common aesthetic experience (such as the urban), creating the vocabulary and language that can either offer openness or isolation and negativity. As with everyday objects, we are often not attentive to its special attributes, but they certainly work on our psyche unconsciously given that all human-made objects and used architectural bodies assume human values. They are the basic stimulus for our daily aesthetic judgments and experiences. Architecture is the one art we cannot do without. As the primary imposing materiality of our environment, creating the basic forms of the urban expanse, architecture conditions the atmosphere of our exterior urban spaces, in fact forming the interiority of urban spaces. In the words of Aldo Rossi, 'as a creation inseparable from civilised life and the society in which it is manifested ... by nature it is collective'. ${ }^{2}$ As the shape giver of our shelter, it surrounds us like a second skin within which we can retreat to our own interiority. Thus, architectural bodies and buildings are the primary constituents of our worldly and individual orientation. Buildings, as well as the cities they construct over time, are always experienced through meanings they suggest, because as a linguistic animal, we always understand objects through the language of their forms. As Gestalt theory has put forth, forms have meanings to which we respond psychologically and through our behavior. I will look at architecture and the city as constructed languages. ${ }^{3}$

Architecture creating the city and our personal habitat offers the basic sensual stimulus that connect us to the world and to ourselves. In the urban environment, architectural bodies affect our psychology and sense of social belonging or can 
be instruments of discord. In our increasingly polarised world, cultural clashes between fundamentalist and populist or secular and left-wing fractions of the society are using modernist forms or religious symbols in architecture or urban designs as oppressive, resistant or concordant forces. Yet, if not made a tool for animosity, the diversities in urban contexts are the means for openness and understanding. In his book Learning from Las Vegas, Robert Venturi was able to bring together already in the 1960s the dialectical forces within the greater urban context and to show that popular forms can give both the highs and lows at the same time. ${ }^{4}$ The artistic, the critical and the populist ideology try to build their societies through architecture. The building of a mosque does not only concern architecture, it creates a society through charity, engineering, land speculation, collecting, consecrating and symbolism. Likewise, "artistic" or "critical" forms have meanings that aim to bring together not only like-minded people but to create awareness beyond conformities.

\section{THE ARCHITECTURAL BODY}

Paul Crowther uses the term "The Body of Architecture" as: 'the medium's distinctive physicality and ... the human body's engagement with it'. I use the term "building as body" in a literal sense, suggesting that architecture is experienced almost as our bodies, and of the inner space of our bodies that we feel, but can only enter mentally. The inside and the outside are two dialectical positions and relate to the inner world and the "other", the outside and alien world. The building is an archetype of the body, and like all bodies and individuals its appearance has a distinct meaning, a specific language. Much like the human body, it is most valuable when we are not made to feel its presence. In the words of Bataille, architecture is what is left after structure; in other words it is the symbolic and spiritual value that makes the essence of architecture. A window is there for us to see outside, to get light and air. We don't need the window, we need the light and the air, we don't need the chair, we need to sit. If the forms are beautiful and attract us by their form, again beauty carries us beyond the material to a spiritual world. This is how Louis Kahn, one of the greatest architects of the twentieth century, talked about architecture. In this sense I find the relation between the body of architecture and the human body to be very indicative: We do not want to be reminded of our body, when we walk we should not feel our legs but rather the energy and the force against gravity, our spirit wants to forget the body. Likewise it is when we forget the physicality of buildings and are attracted by the aura of their spaces and presence that architecture becomes valuable and unique and transcends its physique. Today architecture asserts its physicality generally in the most brutal way, drawing attention to its material being. 
We make contact with buildings in several ways. A personal contact is established when we live or work in it. Even entering a building can create empathy in us through forms that are welcoming, such as doorknobs or a top light that facilitates our entry, much like the entrance to the main building of the Juveskyla Campus by Aalto. This quality of welcome has been observed throughout history: Sullivan's buildings, which are generally of simple form, pay special attention to the entrance articulation both on the outside and the entrance hall. Each building in a city talks to us with its shape, its colour, its position and its physical relationship with people and place. A building can be frightening, chaotic and make us feel insecure, it can be mute, cold and without expression, or intimate and joyful. It can be aggressive, it can have an incoherent form and be confusing, it can be too self-conscious like someone who tries to please and makes the observer uncomfortable, it can want to be something else than what it could be. Like an apartment building trying to become a Swiss chalet, it can try to reach the sky without succeeding - as someone who wants to be on top but always fails, it can be confusing because we do not know where the entrance or the exit is, it can be terribly defensive with all kinds of walls and railings around it as many government buildings are in Ankara, Turkey. A building can be distorted because its function has been changed without appropriate change in its appearance, it can seem awkward because it can look out of place, a building can look terribly old and weak and make us feel uncomfortable, not knowing how to act in front of it or inside it, or it can have an attractive presence, be proud or simply ordinary. As people and all humanly assumed objects, buildings have their own language besides having diverse meanings to different people.

In an architectural setting all our sensory perceptions are stimulated, as our body is affected by diverse qualities - visual, olfactory, kinesthetic, tactile, auditory - we translate these into meanings concerning life and into a language of forms. Architecture also refers to social conditions such as class, gender and politics. Our relationship with the world and with the cosmos is suggested unconsciously in the meanings that arise. Even merely as shelter, architecture relates to differentiating human existence from the rest of nature. A building has in store more poignant and varied perceptual experiences than a place in nature would have because in all architectural forms, the qualities of nature are brought to light in intensified and humanly conceived ways. No matter how much a place in nature is emotionally or aesthetically effective, it is always in some ways mute, inexplicable. According to Heidegger, what is hidden in nature is revealed in art. ${ }^{6}$ It is through architecture that we can abstract or isolate sensual qualities as singular values and enjoy their many phases depending on how they enter our space, creating a silent language. 
Architecture tells us what society and its civil condition is. It expresses the soul of society, and is consequently a sign of transcendent reality. But this also means that it is the soul of power that we meet in architecture. I mean power in both its positive and negative sense. Imagine how proud is a man who builds his own house and gathers his family in it. That is why the natural model for architecture is labour. What we take for granted in a finished architectural work is the result of the love and labour of hundreds of people. Even a simple piece of brick undergoes multiple caring interventions from its very beginning as earth and water and fire. Architecture is not only a symbolic art, as Hegel claims in his book on Aesthetics, but it is a tragic art which leaves the language of most of humanity generally unheard or heard without an objective basis. Thus, as Bataille claims, 'Architecture is society's authorised superego. It speaks to multitudes or silences them'. ${ }^{7}$ It is also tragic because it holds onto memories. The show of power through architecture or urban forms, creating ostentatious spectacles, mesmerizes the masses.

Goethe said that the sacred is what connects souls. According to him, the sacred is when the end and the means to attain it are one and the same thing. ${ }^{8}$ Good architecture that achieves this, retains and radiates the social soul. Ideally this soul is present in the urban reality, as institutions, monuments, memories connect people who are strangers but who assume kinship by being in the same place and by using common institutions. Each institution is the ultimate development and realisation of one of our sense capacity and becomes through this articulation a socialising factor. Music is the development of the auditory sense and a music hall brings people together through their intimate sensory pleasure. Thus architectural bodies representing institutions create the discourse continuing in history and of the diverse aspirations and resistances of whole communities that create the city. Any institutional building has its geneology in the beginning of human communities that have designed forms to meet their needs. Therefore, each building is a contingent of multiple narratives and myths. It is the use and discourse of the community of strangers who come together in architectural spaces that gives shape to the city and creates silent interactions through shapes and symbols.

The connection to the "other" can be realised most effectively and peacefully in contexts where communal events in social spaces join people in shared feelings, such as being in an awesome architectural space or while experiencing the urban excitement of Times Square, for example, or in a park where people can both be alone and with others. Experiencing works of art that elicit positive responses and feelings, or even those that arouse common political outrage is what can erase racial and cultural differences. 
Therefore when they cater to the society, architecture of buildings and architecture of cities can create a bonding process. Alienation, despair and animosity begin to happen in many cities where only the separating forces of racism or Capital are at play. As Lévi-Strauss has so succinctly expressed in Tristes Tropiques: 'Once people begin to feel threatened (besieged) in their geographical, social and mental habitats, they fall into the danger of finding the solution in considering a part of the human species as not belonging to humanity'.

Authentic art created critically, with knowledge and labour, can be the only means to build a sincere human habitat. In architecture and the city, the clarity of spaces, whether public or private, the signs and possibilities for the respectful liberty of use are vital to prevent a crisis of identity and exclusionary nationalism or personal political identifications. Is that possible when each ounce of material is considered as an input to Capital? 
Dennis Hollier, Against Architecture - The Writings of George Bataille, trans. Betsy Wing (Cambridge Massachusetts: A October Book, The MIT Press, 1992).

Aldo Rossi, The Architecture of the City (Opposition Books, MIT Press, 1982), 21.

Rudolf Arhmein, Art and Visual Perception (Berkeley: University of California Press, 1974).

Robert Venturi, Dennis Scott Brown, and S. Izenour, Learning from Las Vegas (MIT Press, 1972).

P. Crowther, Phenomenology of the Visual Arts (Stanford, California: Stanford University Press, 2009), 173-205.

M. Heidegger, "The Origin of the Work of Art," in Philosophies of art and Beauty, ed. Elbert Hofstadter and Richard Kuhns (The University of Chicago Press, 1964), 674.

Hollier, Against Architecture - The Writings of George Bataille, 4.

Ibid., 1x.

Claude Lévi-Strauss, Tristes Tropiques (1973)401 citted in: David Harvey, Spaces of Capital Towards a Critical Geography, 90 (Translation from French J. N. Erzen). 
Crowther, P. Phenomenology of the Visual Arts. Stanford, California: Stanford University Press, 2009.

Heidegger, Martin. "The Origin of the Work of Art." In Philosophies of art and Beauty, edited by Elbert Hofstadter and Richard Kuhns, 674. The University of Chicago Press, 1964.

Hollier, Dennis. Against Architecture - The Writings of George Bataille, trans. Betsy Wing. Cambridge Massachusetts: A October Book, The MIT Press, 1992.

Lévi-Strauss. Claude. Tristes Tropiques (1973) 401 citted in: David Harvey, Spaces of Capital Towards a Critical Geography, 90 (Translation from French J. N. Erzen).

Rossi, Aldo. The Architecture of the City. Opposition Books, MIT Press, 1982.

Venturi, Robert, Dennis Scott Brown and S. Izenour. Learning from Las Vegas. MIT Press, 1972. 


\section{GRADOVI KAO NAČINI STVARANJA SVETA}

\section{Curtis L. Carter}

Rad razmatra Tema "Načini stvaranja sveta" se pojavljuje u radovima filozofa poput Ernsta Kasirera (Ernst Cassirer) i Nelsona Gudmana (Nelson Goodman) (1906-1998.). Kasirer se ovom temom bavi u svom radu Jezik i mit (prevela Suzan Langer (Harper, 1946.)), a Gudman obrađuje "Načine stvaranja sveta" u svojoj istoimenoj knjizi (Hackett, 1978, 1981.). Oba filozofa navode umetnost kao ključan način za stvaranje sveta u svojoj funkciji različitih vrsta simbola. Prateći uvide Kasirera i Gudmana, "Načini stvaranja sveta" se ovde prvo razmatraju u odnosu na zamišljeni svet koji stvara uloge umetničkih dela koje se odnose na gradove. Primeri koji uključuju književna dela J. R. R. Tolkina, operu Kurta Veila i Bertolda Brehta, film kineskog umetnika Ksu Binga, njujorški Hadson Jards, najveći razvoj privatnih nekretnina u istoriji SAD-a do danas, se koriste kao primeri stvaranja sveta u umetnosti i razvoju gradova.

KLJUČNE REČI: STVARANJA SVETA, GRAD, TOLKIN, KURT VEIL / BERTOLD BREHT, KSU BING, HADSON JARDS, GUDMAN, KASIRER

\section{ZGRADE NAM GOVORE}

\section{Jale N. Erzen}

Polazeći od kritičkog pogleda na opšte arhitektonske i urbanističke strukture današnjice, ovaj rad će predstaviti zgrade koje se mogu porediti sa telom, tako što će njihov izraz i značenja koja imaju biti predstavljeni kao jezik forme koji utiče na ponašanje i psihologiju stanovnika u urbanim sredinama. Pozivajući se na arhitektonsku kritiku Žorža Bataja (George Bataille), tvrdi se da su fizički aspekti građevina značajni u onoj meri u kojoj prevazilaze materijalnost i vode ka simbolima i duhovnosti. Zgrade se posmatraju kao različite karakteristike i stavovi u zavisnosti od oblika. Arhitektura se takođe posmatra kao produkt rada i samim tim javna tvorevina koja svoje korene vuče iz korena ljudske kulture. Sve različite institucije su se istorijski razvijale iz različitih čula, postajući kulturna artikulacija i rezultirajući arhitekturama koja povezuje ljude u uživanju u zajedničkim interesovanjima. Dalje se tvrdi da urbani i prostorni oblici koji su zbunjujući u pogledu svojih granica i namena mogu izazvati konfuziju i negativne reakcije. Stoga je važno da jezik urbanih oblika bude pozitivan i jasan.

KLJUČNE REČI: ARHITEKTURA, TELO, JEZIK, FORMA, KULTURA

\section{ŠTA SE DOGODILO SA ESTETIKOM I UMETNOŠCU U PRETHODNIH 100 GODINA? PROTIVREČNOSTI I ANTAGONIZMI - RATOVI TEORIJA! \\ Miško Šuvaković}

Predmet ovog rada su dinamični i transformacioni odnosi između estetike i umetnosti od 1919. do 2019. godine. Prvi problem koji će se raspravljati biće odnos između umetnosti i politike u Bauhausu i umetničkih instituta Sovjetske avangarde. Zatim ću ukazati na razlike u marksističkim konceptima socijalističkog realizma i kritičkoj teoriji o modernoj kulturi i umetnosti. Analiziraću odnos između koncepta autonomije umetnosti, posebno slikarstva i minimalne umetnosti. Poređenje će biti izvedeno između anti-umetnosti (Dada, Neo-Dada) i anti-filozofije (Fridrih Niče, Ludvig Vitgenštajn, Žak Lakan). Osvrnuću se na pristupe od analitičke metaestetike do interpretacije Dišanovih redimejda, izvešću na osnovu toga teoriju umetnosti u konceptualnoj umetnosti. Posebna pažnja će se posvetiti "teorijskim sukobima" između fenomenologije i strukturalizma, kao i poststrukturalizma. Završiću svoju diskusiju identifikujući "estetski uslov” u odnosu na "savremenu umetnost" (feministička, aktivistička, politička, ekološka, participativna i aproprijacijska umetnost). 